\title{
SINONIMSKI NIZ ZA SPISATELJSKU DJELATNOST U SREDNJOVJEKOVNIM BOSANSKIM I HUMSKIM KANCELARIJAMA
}

\author{
Marijana Galić \\ Filozofskl fakultet u Mostaru Bosna i Hercegovina
}

\begin{abstract}
Sažetak
U radu će se proučavati leksemi koji označavaju pisarsku djelatnost u bosanskim i humskim kancelarijama. Korpus se sastoji od 130 srednjovjekovnih bosansko-humskih tekstova od isprave bana Kulina 1189. godine do povelje braće Vlatkovića 1493. godine. U formulama najčešće datacije pronalazimo uz ime pisara i funkciju koju je obnašao. Tako se $u$ istraživanome korpusu stvorio kompletan sinonimski niz za tu spisateljsku djelatnost. To je: pisarb (pisьcb), dijakb, gramatikb (gramatigb), logofetb, notarb, protovistijarb. Taj je sinonimski niz od polazišne važnosti za daljnje proučavanje ostalih leksema u srednjovjekovnome korpusu. Pisari su ti kojima možemo zahvaliti na izgledu pisma, njegovanju korespondencije, administraciji uopće i jeziku na kojem su isprave pisane. Razvoj pismenosti u bosansko-humskoj kancelariji, korespondencija s dubrovačkom kancelarijom, nastanak i razvoj hrvatske ćirilice ili bosančice sadržaji su koji u posljednje vrijeme zaokupljaju jezikoslovce. Isprave su najbolji odraz kancelarije. One prikazuju pismo, jezik, stil, autore isprava, naručitelje isprava, mjesto gdje su izdane i kome se šalju te mnoge druge podatke. Uvidom u administrativne tekstove bosansko-humske kancelarije otkriva se čitava lepeza različitih leksema. Pisari su i njihovi tekstovi, kao i tlo na kojem su nastale, nepresušna tema ne samo zbog povijesnog značenja i sadržaja nego zbog grafije, jezika i riječi bosansko-humskoga srednjovjekovlja.
\end{abstract}

Ključne riječi: bosansko-humske kancelarije, pisarb (pisьcb), dijakb, gramatikb (gramatigb), logofetb, notarb, protovistijarb.

\section{UvoD}

$\mathrm{U}$ ispravama se bosanskih i humskih vladara može uočiti sinonimija kao posebna pojavnost kroz srednjovjekovna stoljeća. Uočava se to ponajprije iz naziva za pisarsku djelatnost. Promatrat će se nazivi za pisare od povelje bana Kulina 1189. godine do povelje humske braće Vlatkovića 1493. godine. Kroz ta su četiri stoljeća neminovne i promijene u jeziku. O jezičnim se promjenama promišlja otkada postoji jezik. Budući da jezik služi kao sredstvo komunikacije, od njega se očekuje da bude uvijek i svugdje isti i razumljiv svim govornicima. Međutim, baš kao što je priroda čovjeka promjenjiva, takva je i narav jezika (Barić, 2013, str. 61). Sinonimi su možda najbolje ogledalo promjena u jeziku. Leksemi istoga sadržaja, a različita izraza zovu se sinonimi. Odnos između dviju ili više riječi različita izraza a istog sadržaja zove se sinonimija (Zrinjan, 2006, str. 17). U radu se proučavaju srednjovjekovne isprave, a sinonimija koja je zastupljena $u$ ispravama ostvaruje se kroz vremensku raslojenost leksika, a kako su nastale na bosanskom i humskom tlu govorimo i o prostornoj raslojenosti leksika. Također, isprave su administrativni tekstovi pa govorimo i o stilskoj raslojenosti leksika. Potrebno je zbog toga utvrditi jezične okvire u kojima se sinonimija ${ }^{1}$ ostvaruje s obzirom na teritorijalnu, stilsku i vremen-

1 Sinonimni se odnosi osnivaju na opreci minimalno dviju leksičkih jedinica koje čine sinonimski par ili više njih, a tada 
sku raslojenost leksika (Tafra, 1996, str. 76). Važno je naglasiti i to da su neki sinonimi u bliskoznačnom odnosu, zapravo sinonimi koji su zamjenjivi samo u određenom kontekstu. Neki su sinonimi moguće istoznačnice, ${ }^{2}$ sinonimi koji su zamjenjivi u bilo kojem kontekstu. Istoznačnice se povezuju u nizove. $U$ tim je nizovima jedna riječ dominantna. To je ona riječ koja je stilski neutralna, dok su ostale riječi sinonimskog niza stilski obilježene riječi pa bi se to trebalo vidjeti i u njihovoj leksikografskoj obradbi (Mihaljević, 2002, str. 192). Brojni su sinonimi u srednjovjekovnim ispravama bosanskih i humskih kancelarija, a kako i ne bi bili brojni kad je promjena u jeziku od četiri stoljeća zbog unutarjezičnih i izvanjezičnih razloga nezaobilazna. Stoga se posebno mogu proučavati sinonimski odnosi u istraživanom korpusu. U ovom će se radu pokušati analizirati sinonimski niz: pisarb (pisьcb), dijakb, gramatikb (gramatigb), logofetb, notarb, protovistijarb.

\section{Spisateljska djelatnost bosanske i humske kancelarije}

$\mathrm{U}$ ispravama srednjovjekovnih bosanskih i humskih ćiriličnih tekstova pronalazimo nazive za pisare poput: dijakb, gramatikb (gramatigb), logofetb, notarb, protovistijarb. Najstarija isprava iz srednjovjekovnoga korpusa navodi ime pisara, a to je dijak Radoje. Već njegov pravni tekst odaje književno kultiviranu osobnost, pisca obrazovanog u duhu slavenske tradicije s razvijenim senzibilitetom za jezično-stilsko oblikovanje (Hercigonja, 2004, str. 136). Pisari bosanskih i humskih banova, kneževa ili župana u prvim ispravama do kralja Tvrtka I. nazivaju se dijaci, notari ili gramatici, a neke isprave nisu potpisane pa je pisar anoniman. Jedan od prvih pisara bio je notar Paskal koji je najizrazitiji pisar ćirilske poluminuskule iz prve i početka druge polovice XIII. stoljeća i pod njegovim vodstvom dubrovačka kancelarija bila je vrlo važan kulturni centar onoga doba (Vrana, 1957, str. 334). Zbog toga su postojale neke pretpostavke da su se u dubrovačkoj kancelariji sastavljale isprave koje su bile nošene stranim vladarima na potpis (isto, str. 329). Međutim, Josip Vrana to odlučno u svome izlaganju odbacuje. Kada Tvrtko I. Kotromanić postaje kralj, za pisara dolazi logofet Vlade, srpski pisar. Isprava koju je napisao logofet Vlade, započeta 10. travnja 1378. godine u Žrnovnici, a dovršena 17. lipnja 1378. godine u Trstivnici, uistinu je bogata, kako Čremošnik navodi, najsvečanija Tvrtkova povelja pisana bosančicom na neobično tankom pergamentu, talijanske izrade (Čremošnik, 1950, str. 119). On u kraljevsku kancelariju uvodi jezik i stil raških povelja, što je naročito iznimno izraženo u prvim dijelovima dokumenata - intitulaciji i arengi, svečanom uvodu u kome se iznosi opća motivacija akta, povezana s vjerskim shvaćanjima tog vremena prema kojem je vlast dar Božji, potreban da se prenosi i na druge (Dizdar, 1997, str. 21). Vjerojatno je najpoznatiji pisar kraljevskih isprava Tomaš Lužac. Pisao je latinske isprave bosanskog kralja Tvrtka I., a poslije smrti Tvrtka I. bio je pisar (logofet) isprava kralja Dabiše i kraljice Jelene. Prvotno je bio pomoćnik logofeta Vladoje, a možda čak i njegov učenik (Brković, 1998, str. 338).

„U ispravi kralja Dabiše iz 17. srpnja 1392. godine navodi dugačke biblijske elemente, a u kasnijim ispravama uočavamo i ikavske elemente kao u formuli datacije gdje upotrebljava jat (ê): pod lêti togda gospoda hrêsta roždenija 139 i drugo lêto m(ê)s(e)ca julja · $17 \cdot d(a) n \cdot$, dok $\mathrm{u}$ ispravi iz 18. veljače 1393. godine u formuli datacije koristi ikavicu: pisano u sutisci $\mathrm{m}(\mathrm{i}) \mathrm{s}(\mathrm{e}) \mathrm{ca}$ ferbv(a)ra $18 \mathrm{~d}(\mathrm{a})$ nb lito togda rožbstva hrbstova · 139 - tretie."

Zašto je mijenjao stil pisanja iz ijekavskog u ikavski govor, ostaje otvoreno pitanje. Možemo pretpostaviti da su isprave pisali ljudi koji su morali biti učeni i školovani za kancelarijsku

govorimo o sinonimskom nizu. Sinonimski niz je leksičko-semantički mikrosustav. Sinkronijski gledano, on je otvoren. U njemu je jedna riječ središnja, stilski neutralna, s najvećim opsegom značenja (Tafra, 1995, str. 18). U sinonimskom se nizu ta središnja, neutralna riječ naziva nadređenica odnosno hiperonim, a ostali su leksemi u nizu podređenice odnosno hiponimi. Stoga se u kontekstu hiperonim može zamijeniti hiponimom, ali ne i obrnuto (Petrović, 2005, str. 197): pisarb jest i dijakb i protovistijarb, ali svaki dijakb ili protovistijarb nisu obavljali samo službu pisara.

2 Takve sinonime koji su međusobno zamjenjivi u svim kontekstima nazivamo potpunim sinonimima ili istoznačnicama (Samardžija, 1995, str. 18). 
djelatnost, a nerijetko su obnašali dužnost tajnika, blagajnika, poklisara ili pak protovistijara. Za imena pisara znamo prema formulacijama na kraju povelja što je, uglavnom, dosljedno prakticirano u bosanskim kancelarijama mada ima slučajeva i da je pisar ostao anoniman, a vrlo se rijetko dešavalo da je izdavalac potvrde ili priznanice pisao vlastoručno, kao što je, npr. bio slučaj s Vladislavom, sinom hercega Stjepana (Kuna, 2008, str. 332). Takve su dvije isprave kneza Vladisava Hercegovića iz oko 1450. godine i 15 . kolovoza 1451. godine iz humske kancelarije, isprava kneza Vlatka Popovića iz 1. siječnja 1466. godine i kneza Žarka humskog iz 26. svibnja 1466. godine. Ipak, jedan dio isprava nije potpisan. Vjerojatno je to bila praksa pojedinih pisara da se isprave nisu potpisivale tako da bi se do autentičnosti isprave trebalo doći drugim putem istraživanja. Pisari u srednjovjekovnim bosanskim i humskim kancelarijama su: dijak Radoje (ban Kulin), gramatig Desoje (ban Ninoslav), notar Paskal (ban Matthaeus Ninoslav, župan Radoslav), dijak Priboje (ban Stjepan Kotromanić); dijak Radjen (Jelisaveta, supruga bana Stjepana Kotromanića, kćer srpskoga kralja Dragutina), dijak Kupusac (ban Stjepan Kotromanić), dijak Dražeslav (knez Vladislav, kneginja Jelena, ban Tvrtko Kotromanić i njegov brat Vuk, ban Tvrtko Kotromanić), dijak Brajan (ban Tvrtko Kotromanić), logofet Vlade (kralj Tvrtko I. Kotromanić), dijak Grubanac Hlapčić, Imoćanin (Radič Sanković), dijak Raško (Radič Sanković), logotet Tomaš Lužac (kralj Dabiša, kraljica Elena), dijak Radosav Milosalić (knez Pavao Radinović), dijak Stipan Dobrinović (kralj Stefan Ostoja), dijak Hrvatin (kralj Ostoja), logothet Mileta Popović (vojvoda Radič Sanković i župan Bjelijak), dijak Vukorija (kralj Ostoja), dijak Milivoj (vojvoda Hrvoje Vukčić Hrvatinić), Novak Gojčinić (kralj Stefan Tvrtko Tvrtković, kralj Stjepan Ostojić), logotet Tomaš Bućanin (kralj Ostoja), Dobrilo Rašković (knez Grgur Vukosalić), dijak Vladić (kralj Stjepan Ostojić, Stefan Tvrtko Tvrtković), Pribisav Pohvalić (vojvoda Sandalj Hranić), dijak Grubač (Sandalj Hranić), logofet Dušan (kralj Stefan Tvrtko Tvrtković),Vlatko Maroš (vojvoda Radosav Pavlović), dijak (logofet) Ostoja (Radosav Pavlović), dijak Pavle (kralj Tvrtko II. Tvrtković), dijak Vlatko (vojvoda Stjepan Kosača), dijak Ivan (vojvoda Radosav Pavlović, vojvoda Ivaniš), Radivoj Hrstić (kralj Tvrtko II., kralj Stefan Tvrtko Tvrtković), knez Vukman Jugović (herceg Stjepan Kosača), dijak Vukša (vojvoda Stjepan Kosača), protobistar knez Restoje (Tomaš Ostojić), dijak Tvrtko Sekulović (Tomaš Ostojić), Radič Grupković (herceg Stjepan Kosača), Vladisav Hercegović (vlastoručno), dijak Božidar (herceg Stjepan Kosača), Radivoj Dobrišević (herceg Stjepan Kosača), dijak Branoš (kralj Stjepan Tomašević), dijak Sanko (herceg Stjepan Kosača), dijak Radoje Dobrišević (herceg Stjepan Kosača), knez Vlatko Popović (vlastoručno), knez Žarkohumski (vlastoručno); dijak Ivko (hercežica Cecilija, herceg Vlatko), dijak Vukman (vojvoda Vladisav Hercegović), mitropolit David (herceg Vlatko), dijak Radonja (herceg Vlatko), Vukašin Gizdavić (herceg Vladislav). Pisac isprave - vrlo dobar stilist s osjećajem za vrijednost jezika, smislom za izražajne nijanse, sugestivan i slikovit izričaj - efektno oblikuje tekst dajući mu jedan osobnoemotivan ton tako da iskaz na mahove poprima značajke intimnih refleksija, ispovijesti o zbivanjima koja su relevantna za pravni čin darivanja (Hercigonja, 1986, str. 120).

Bosanski su i humski dvorovi imali vlastite kancelarije u kojima su djelovali pisari bosanskih i humskih vladara i velmoža, koji su obavljali cjelokupnu korespondenciju, a vrlo rijetko se radi o pismenim pojedincima koji su sami napisali neki relevantni opširni dokument (Kuna, 2008, str. 324). U ispravama su pisari uz ime i prezime navodili i djelatnost koju su obavljali u kancelarijama pa se stvorila čitava lepeza istoznačnih ili bliskoznačnih leksema koji tvore sinonimski niz. Tako će se analizirati sinonimski niz pisarb (pisbcb), dijakb, gramatikb (gramatigb), logofetb, notarb, protovistijarb kako se potpisuju najpismeniji ljudi toga doba.

$\mathrm{Na}$ dvorovima oblasnih gospodara, kao središtima upravne oblasti, izdavane su isprave, sklapani ugovori, dodjeljivane privilegije i drugi akti koje je sastavljao pisar. On se u ispravama naziva dijak, logotet, dijak veliki, dijak nadvorski, gramatik. U njegova je zaduženja ulazilo sastavljanje i prijepis isprava i njihovo čuvanje te primanje stranih pisama, povelja i drugih isprava. Njegovo se ime unosi na kraju teksta i ono je bilo jamac vjerodostojnosti teksta (Jurčević, 2016, str. 56). 


\section{Pisarb (pisbcb)}

Pisarb (pisьcb) je službenik kancelarijske djelatnosti na dvoru bosanskih i humskih vladara. Zbog izvanjezičnih razloga ta je djelatnost postala historizam koji je u srednjem vijeku bio kancelarijski službenik nižeg ranga koji radi administrativne poslove (Anić, 2004, str. 1033). Kroz njegove ruke prolazili su svi akti dvorske kancelarije te je on, bolje od svih, mogao da sagleda kontinuitet pregovora o nekom vanjsko-političkom pitanju ukoliko je njihov sadržaj ulazio u diplomatsku prepisku (Usp. Babić, 1972, str. 109).

Staroslavenska riječ pismę (imenica srednjega roda) značila je 'slovo', a riječ slovo (također srednjega roda) značila je 'riječ' (Mamić, 1996, str. 118). Prema tomu pisarb (pisbcb) bi predstavljao službenika koji doslovno piše slova ili riječi. Iz te su se osnove razvile radne imenice pisăc i pisar i mnoge druge sufiksalne ili prefiksalne tvorenice koje traže svoje pravo obrade. Uz činjenicu da se isti autor mogao poslužiti različitim tvorbenim postupcima da bi dobio riječ istoga značenja, presudna je za stvaranje sinonima bila široka geografska rasprostranjenost prvoga slavenskog književnog jezika (Damjanović, 2003, str. 46). Naziv za kancelarijsku djelatnost pisarb (pisbcb) nastala je iz staroslavenskoga jezika i kao takva ušla i u starohrvatski jezik, a danas je promatramo kao historizam. Utemeljeno je i mišljenje da historizmi nemaju svojih pravih sinonima, a u ovome je nizu jedna domaća riječ, a ostale su posuđenice i historizmi. Međutim, navedene lekseme promatramo u vremenskom kontekstu njihove uporabne snage. Oni su zbog povijesnih promjena ostali u određenome povijesnom razdoblju i postali pasivni leksik. Tako će se promatrati s obzirom na vrijeme njihovog nastanka i aktivnog korištenja u povijesnim službenim administrativnim dokumentima.

Zašto se neki službenici nazivaju pisarima, neki dijacima ili nekim drugim gore navedenim leksemima? Vjerojatno zato što su se u bosanskim pisarnicama, ovisno o širenju Bosne i odnosu s drugim srednjovjekovnim državama, pojavljivali pisari s inonarječnih područja, koji su nerijetko određivali stil i jezik u kraljevoj pisarnici (Šabić, 2014, str. 19). Leksem se pisarb ne pojavljuje $u$ istraživanome korpusu, već se pojavljuje u drugim izvorima kao općeniti naziv ili hiperonim za sve dvorske službenike koji su se bavili pisanjem u kancelarijama pa se zbog toga analizirao taj leksem, a postoji i primjer za radnu imenicu pisbcb koju prikazujemo:

- a se pisa dražeslav diêkb g(ospo)d(i)na bana tvrbtka nadvorbni pis(a)cb a prbvo diêkb (P. $18)^{3}$

U primjeru se iz isprave bana Tvrtka koju je potpisao dijak Dražeslav Bojić 1353. godine na Suhoj na Prozračcu može uočiti glagol pisati koji je ie., baltoslav., sveslav. i praslav. (Skok, 1995, str. 662) glagol, a iz iste su se osnove razvile radne imenice pisarb i pisbcb. Osim glagola pisati i radne imenice pisьcb, navedeni pisar sebe potpisuje i kao pisca, ali prvo dijaka, što navedene lekseme čini kontaktnim sinonimima, a nastojat će se prikazati terminološka razlika između tih dvaju leksema.

\section{Dijakb}

Leksem dijakı grecizam je, a i taj je leksem historizam u značenju 1. učenik vjerske škole 2. pisar vladara ili velikaša 3. a. učen čovjek b. onaj koji je vješt latinskom jeziku (Anić, 2004, str. 213; Hrvatski enciklopedijski rječnik, 2002, str. 241). Dijaci su pisari, ali i vrsni poznavatelji latinskoga jezik, jer pridjev dijački označava stari naziv za latinski jezik ${ }^{4}$ (Isto). Međutim, u prvome

\footnotetext{
3 Potrebno je naglasiti da se korpus sastoji od 130 isprava pa se zbog opsežnosti izvora nije naveo popis. Taj se popis Izvori (Administrativno-pravni tekstovi) prema kronološkom slijedu može pronaći u mome Kvalifikacijskome radu Neki sinonimski nizovi u bosansko-humskim administrativnim tekstovima. Cjelokupan korpus sadrži i rječnik: Nakaš, Lejla (2011). Konkordancijski rječnik ćirilskih povelja srednjovjekovne Bosne, Sarajevo: Društvo za proučavanje srednjovjekovne bosanske historije, knjiga X., Filozofski fakultet u Sarajevu.

4 U kancelarijama se pisalo latinskim jezikom i pismom latinicom kada se diplomatska korespondencija odnosila na susjedne države i njihove vladare, a narodnim se jezikom i hrvatskom ćirilicom ili bosančicom dopisivalo na podru-
} 
se objašnjenju dijaka navodi kao učenika vjerske škole, pa se ponekad diêkь prevodi kao đakon (Damjanović i ostali, 2004, str. 69). Đakon je u ranokršćansko doba pomoćnik biskupa (Anić, 2004, str. 276) i historizam koji je iz grčkoga jezika prešao u latinski jezik. Đakon je ponekad i upravitelj općinskih dobara i skrbnik sirotinje i bolesnika u najranije kršćansko doba; kasnije: crkveni sluga i pomoćnik pri bogoslužju; početni svećenički čin u crkvi; pomoćni svećenik (Anić, Klaić, Domović, 2001, str. 334). Negdje se dijaka prevodi kao đaka, ${ }^{5}$ učenika, dok pridjev dijački prevodi kao latinski (PSHK, 1969, str. 500). Dakle, te se riječi dovode u vezu: dijakb, đak i đakon. Ta se veza ostvaruje vjerojatno refleksom jata ili sekvencom ja: tako bi bio dijakb, a iza poluglasa bi bio dojakь ili dıêkь gdje bi, pretpostavlja se, odgovarao đakonu,adêkь bi tako bio đak ${ }^{6}$. U svakom slučaju, odmah se može ustanoviti da je mjesto pisara isprava u hrvatskoj dvorskoj kancelariji bilo vrlo važno i da su ga u početku popunjavali crkveni službenici nižih crkvenih redova (đakoni i svećenici u službi kapelana), a kasnije većinom službenici višeg crkvenog reda (biskupi) (Brković, 1998, str. 330).

Vjerojatno se zato i prevodi u nekim slučajevima dijakb kao đakon ili kao đak. Poveznica je i činjenica da su to pisci koji su poznavatelji latinskoga jezika, a to znamo da su oduvijek bili svećenici. ${ }^{7}$ Dijakova je služba bila da obavi cijelu kraljevsku korespondenciju, da sastavlja državne listine i da ih što čistije i ljepše prepisuje (Truhelka, 1901, str. 105).

Donosimo sve primjere oblika riječi dijakь koji se pojavljuju u korpusu srednjovjekovnih bosanskih i humskih administrativnih tekstova:

- a upisa diêkь vladiĵs poveliniemь kralevbstvaa mi (P. 77, 71, 113, 98, 11, 20, 18, 21, 111, $96,87,62,125,61,57,22,56,116,127,128,123,115,120,1)$

- a upisa dıjakь ivanь po zapoviedi g(ospo)d(i)na mi voevodje radosava (P. 88, 94, 83, 85, 78, 93)

- a upisa dıêkbivanь po zapovêdi g(ospo)d(i)na mi voevode radosava i gospoe todore i kneza ivaniša (P. 91)

- a pisa vlatko marošb dijakb nadvorni g(ospo)d(i)na voevode radosava (P. 76, 16, 13, 114, $112,105,38,53,95,106,60,107)$

- a se pisa grubanacb hlapsčiĵ (i)moĵaninь rabs župana bêlbêka i voevode radiča i niju diê[kb] (P. 37)

- a se pisa dražeslavb diêakb(P. 19)

- a se pisa pribisavb dêakb banb stipan(a) (P. 14, 89)

- upisa branošb dêkb po zapovidi g(ospo)d(i)na mi g(ospo)d(i)na kr(a)la stipana (P. 110)

čjima Bosne i Huma, ali i Dubrovnika. Kada se radilo o jednom jeziku, pisane su u dva primjerka, svakoj stranici po jedan, a kad se radilo o dva jezika, onda u četiri primjerka, svakoj stranici po dva primjerka (Brković, 2002. str. 191).

5 Diaconus, clericus, scriba, studiosus literarum. Najstariji je oblik dijakъ, dijakь, dijak, kasnije je $i$ ispalo: djak te je taj oblik potvrđen od XV. stoljeća. Kasnije se dj kod tog oblika saželo u đ: đak (Usp. Akademijin Rječnik = 1886, str. 956). Zapravo je đak zastarjelica u značenju student (Anić, 2004, str. 276). Đak je isto što i pisar (značenje se razvilo otud što su se u srednjem vijeku skoro samo redovnici, svećenici bavili knjigom. Od prvih vremena do 15. st. tako se zove pisar koji ima osobitu službu na velikaškim dvorovima) (Šetka, 1976, str. 76). Potrebno je naglasiti i to da se leksem dijakb pojavio s prvom poveljom bana Kulina, ali se u korpusu ponovno javlja tek krajem 14. i u 15. stoljeću.

6 Gluhak u svome rječniku upravo objašnjava tu razliku između dijaka, đaka i đakona. Od starijeg dijâk (usp. tako csl. dijakъ, sln. diják), što je iz srlat. diacus, gen. diaconis. Srednjolatinska je riječ iz grč. diákonos „sluga; službenik; posluženik" preko diaconus (iz čega je - iz grčkog ili iz latinskog - npr. u XVI. st. djakon, danas đàkon; usp. đakònija „slatka hrana” od starijega dijakonija „red; služba; hrana đakonova”, što je iz grč. diakonía). To je kulturna riječ hrvatske terminologje. Iz srlat. diaconus jest žäkan, gen. žäkna (Gluhak, 1993, str. 217).

7 Takav je naprimjer bio i dijak Tvrtko Sekulović koji napisao ispravu kralja Tomaša iz 22. kolovoza 1446. godine u Vranduku. Taj je pisar ustvari poznati krivotvoritelj fra Luka Velimirović ili Vladimirović. Taj se franjevac služio raznim pseudonimima čineći lažne isprave s ciljem da se ime Vladimirovića nađe među imenima bosansko-humske vlastele (Brković, 1998, str. 339-340). lako je bio krivotvoritelj, bio je svećenik i poznavatelj latinskoga jezika o čemu svjedoči Tomaševa latinska isprava iz 24. lipnja 1446. godine. 
TEORIJSKI I PRAKTIČNI PROBLEMI I RASPRAVE

- pisa kupusacb bana stipana diêk (P. 15)

- pisa stipanı dobrênovî̂b kralestva mi dêêkb(P. 54)

- i moga kujjanina ôstoju dbjaka(P. 83)

- danı estb ôd ruke stipana dobrinovij̄a kralestva mi dêêka amnь (P. 56)

- i po knezu brailu tezalwvikju i po ôstoi dbjaku čeljaadniku (P. 81)

- i za veje virovanıe zapovidihь kralevbstva mi zapovidıju našemu diêku pavlu upisati tai našb ôtvoren b list (P. 84, 120, 115, 116)

- iôĉe primihı ôdı rečenôga kneza vlasteô i vse ôpjine vlastewô duborvačcihı kôe namb pôslaše po rečenômb sluzi našemu po radôsavu dêaku (P. 89)

- kako primismo ôdı mnogo počtenoga kneza i vlasteô dubrovbčbcêhь po našemb sluzê i dijaku po radivoju šiglicu s našiemb listomb vêrovaniemb (P. 95, 117, 118)

- erb primismô ôdb počtenoga kneza vlasteô i vse ôpjine vlasteô dubrovačkihı kôe namb poslaše po radôsavu $d($ (b)êku dvie tisuĵi perprb dinari (P. 89)

Iz primjera možemo vidjeti da je dijakı obavljao još neke dužnosti osim dužnosti pisara.

\section{Gramatikb (gramatigb)}

Gramatikb je također kancelarijski službenik koji je obavljao administrativne pisarske dužnosti na bosansko-humskom dvoru ${ }^{8}$. Jednoč se dijak bana Ninoslava, Desoe, naziva i gramatikom (Truhelka, 1901, str. 105). Od riječi slovo u našem današnjem značenju izvedena je

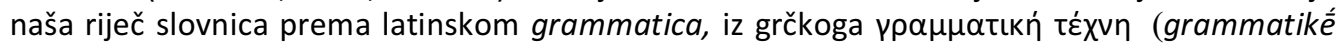
téchnē), što je u vezi s grč. үpó $\mu \mu \alpha$ (gramma), a znači 'slovo' (Mamić, 1996, str. 118).

Leksem gramatika tumači se kao lingv. proučavanje sustava jezika i njegovih zakonitosti, glasovnih osobina, sustava i funkcije riječi, njihovih skupova, veza i rečenica; slovnica (Anić, 2004, str. 376) dok je gramatičar (imenica muškoga roda) (gramatičarka - imenica ženskog roda) onaj koji se bavi gramatikom, koji proučava sustav nekoga jezika (glasove, oblike, sintaksu itd.) (Nav. mj).

Skok u svome rječniku tumači ovako:

"carsko rusko pismo«, gramola (crkveni termin) »dekret za vladiku«, bug. grāmata. Od gr. pl. үpó $\mu \mu \alpha \tau \alpha$. Odatle poimeničen pridjev na sufiks -tkós gramatik m (Travnik) " pisar«, tako i u 13., 14. i 15. v. gramatig pored -ik »scriba, nótárius",

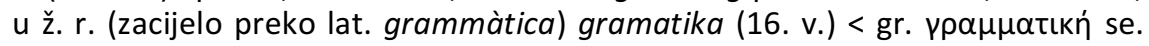
$\tau \varepsilon ́ \chi u \eta ~ » a r s «)$ = stsrp. (15. v.) gramatikija (dodatak -ja kao u ćefalijad), s pridjevima na -bn >-an gràmatican, gramatički, gramatičar. Odatle prevedenica slovnica (hrv.) (Skok, 1995, str. 606-607).

Lekseme gramatika, gramata ili pak gramatičar dovodimo u vezu s prijevodom slovo, kao i prethodni leksem pismę. Leksem pismę definirao se kao staroslavenski leksem, a gramatika, gramata ili gramatičar, kao i gramatikb su posuđenice. Zapravo je isti slučaj da se od imenice ženskoga roda gramata izvela radna imenica muškoga roda gramatikb. Dobivamo potvrdu da su i gramatici bili pisarski službenici u bosanskim i humskim kancelarijama (ne osoba koja proučava sustav jezika prema hrvatskom standardnom jeziku). Prema analizi leksema gramatikb može se zaključiti da su pisarb i gramatikb ${ }^{9}$ moguće istoznačnice, jer i pismę i grama

8 Ovaj leksem pronalazimo samo u dvije isprave. $U$ ispravi bana Ninoslava od prije 1232. godine imamo potpis pisara gramatigb, a u ispravi bana Stjepana Kotromanića iz 23. listopada 1332. godine imamo oblik gramatikb. Razlika od jednoga stoljeća donosi i razliku u pisanju na kraju riječi gdje se $g$ zamjenjuje $s k$, ali poluglas ostaje iza obadva suglasnika.

9 Pisar, usporedi đak (Akademijin Rječnik, 1888, str. 383). 
znače slovo, a gramatici su isto što i pisari. Razlika je što je pisarb staroslavenska riječ, a gramatikb potječe iz grčkoga jezika. Tu se uočava značenjska bliskost jezika u kontaktu. Primjeri leksema gramatikb su:

- a se pisahь imenem b desoe gramatigь bana ninoslava veliega bosnıskoga tako vêrno kakore u prbvyhb (P. 2)

- prêpisahı ôdı zapovedi kneza dubrovačkoga i svega vikja co im se videlo toi pisahı ni prêmokohь ni umokohь i zapečatihs pečatju ôpkine dubrovačke i potvrıdihь jako da je vsakomu verovano jako gramatikb ôpkine dubrovačke u vrême kneza mavržtika uplukenie i(su)s(a) h(rist)a $\cdot 1332 \cdot$ lêto indiktiona $\cdot 15 \cdot$ miseca oktobrja $\cdot 23 \cdot($ P. 16)

\section{Logofetb}

Osobito važan čin na dvoru obnašao je dijakb za koga je uobičajila i grčka oznaka logothet, logofet (Truhelka, 1901, str. 105). Leksem logofetb dobiva svoju uporabnu snagu onda kada Bosna postaje kraljevstvo jer nakon krunjenja kralja Tvrtka I. u bosansko-humsku se kancelariju pokušavalo uvesti elemente srpske kancelarije. Između ostaloga i notari se od tada uz izraz dijaci počinju zvati logofeti (Brković, 1998, str. 33). Skok navodi da je -log inače drugi dio riječi u stranim složenicama, ali u ovome se slučaju riječi logo- nalazi kao prvi elemenat složenice logoteth (stsrp., 1378.) = logovet = logopeth (1369.) = lôgofet (tako i tur. i rum. izgovor

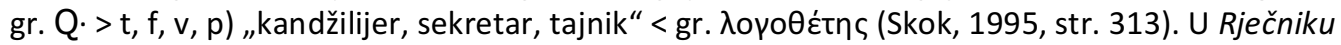
stranihriječi pronalazimoobjašnjenje prvoga elementa složenice logo- (grč. logos) predmetak u složenicama sa značenjem: riječ, govor, razum, um (Anić, Klaić, Domović, 2001, str. 823). Brodnjak u svome Rječniku razlikaizmeđu hrvatskoga i srpskoga jezika za riječ logotet kaže da je grecizam i historizam te da je to pisac, brzopisac; visoki dvorski činovnik kod srpskih srednjovjekovnih vladara (Brodnjak, 1992, str. 270). Ipak je zanimljivo Šimundićevo tumačenje spomenute riječi u jezičnoj analizi jedne Dabišine povelje gdje se navodi da je logofetı kao imenica muškoga roda tajnik ili računar, odnosno čovjek koji računa (Usp. Šimundić, 1996, str. 98). No, i ovdje vidimo nedostatke analize navedene riječi, ponajprije u obliku računar. Ipak ćemo se složiti ako kažemo da su pisari bili i tajnici u dvorskim kancelarijama. Ako je tumačiti prema prvome elementu složenice logo-, onda bismo se opet vratili na lekseme pismę i grama koje označavaju slovo, a logos riječ pa su prema tome bliskoznačnice. Međutim, prema Brodnjaku možemo zaključiti da je logofetb u istoznačnom odnosu s pisarbom i gramatikbom jer se misli na službenika, pisara (pisьca), a potvrđuje i Brkovićevu tezu da su na bosanski dvor došli sa srpske strane nakon krunjenja kralja Tvrtka I. Sve oblike tog leksema promatramo u primjerima koji slijede:

- a upisa vazljubleni logofetb kralevbstva mi tomašb buĵanininı (P. 63, 75)

- sije sbvrbši se $m(e ̂) s(e) c a$ ijunja $\cdot z$ ï $\cdot(=17) d(b) n b$ a pisa logofet(b) vlade (P. 25)

- a pisa ôstoja logôfetb (P. 81)

- ôd ruuke mene ôstoe logofeta pisaanô (P. 81, 63, 41, 46, 47)

- pisa novakb goičiniĵb log(o)petı kral(ev)stva mi na našemb stolınomb mêsti u sutiscê (P. 73)

- a upisa g(o)sp(o)scva mo logothetb mileta popovikb (P. 59)

U svim primjerima vidimo da je logofeto isto što i pisarb bosanskoga dvora tako da se te leksičke jedinice potpuno podudaraju na izrazno-sadržajnoj razini (Tafra, 2003, str. 434). Leksem je logofetb s pisarom zamjenjiv u svakom kontekstu i u tome su slučaju moguće istoznačnice, premda je logofetb grecizam, a leksem pisarb slavenskoga podrijetla, oni ipak pripadaju istoj ortografiji, idiomu i vremenu. 


\section{Notarb}

Notar je danas službena osoba koju češće nazivamo javni bilježnik. Notar je tako službenik ili ovlaštena osoba koja sastavlja javne isprave, ovjerava potpise, prijepise i druge dokumente; javni bilježnik, pisar, brzopisac, notaroš (Anić, 2004, str. 834; Hrvatski enciklopedijski rječnik, str. 834). Latinska riječ nota je znak, oznaka, podsjetnik; pismena primjedba, zabilješka, napomena radi dopune i objašnjenja nekog mjesta u knjizi; u diplomaciji: formalno priopćenje jedne vlade drugoj; trg. kratak račun, privremena priznanica, zabilješka koja služi kao potvrda o prijemu robe itd. (Anić, Klaić, Domović, 2001, str. 961). Tako bi notarb bio osoba koja piše znakove (note) i taj leksem dovodimo opet u sinonimski odnos s pisarbom. Notarb je imenica muškoga roda kao i prethodni leksemi. To je radna imenica na -ar< lat. -orius notar, gen. -ara m (15. v., Dubrovnik) < tal. notaro "bilježnik“ = notarij (Skok, 1995, str. 525) kao namještenik koji piše ili bilježi znakove i prema takvoj tvrdnji odgovarao bi pisaru, odnosno bilježniku. Znakovi ili note slova su (pismę i grama) pa su i ti leksemi po osnovi u istoznačnom odnosu. Uvjetom sinonimičnosti riječi jest njihovo semantičko podudaranje i mogućnost upotrebe jedne riječi (sinonima) umjesto druge (Tafra, 1995, str. 19). Potvrđuje to iRječnik stranih riječi: brzopisac, onaj koji piše pomoću kratica ili znakova (notae), pisar (Anić, Klaić, Domović, 2001, str. 961). Notarske nam isprave (kao i imbrevijature u notarskim knjigama), neprijeporno, najizravnije posreduju mnogobrojne aspekte života vremena i sredina u kojima su pisane (Hercigonja, 1994, str. 98). U istraživanome korpusu nemamo primjer leksema notarb, no primjer za notarij ili bilježničku službu imamo, ${ }^{10}$ a misli se na dubrovačku kancelariju ili notarij:

- u drugo kratb druge šestb tisuĵb dukatb kako se udrıži upisano u notari dubrovačkoj (P. $127,126)$

\section{Protovistijarb}

Na posljetku ovoga sinonimskog niza preostaje analiza bliskoznačnice koja se pojavljuje u korpusu srednjovjekovnih bosanskih i humskih administrativnih tekstova, a to je protovistijarb. Važna je funkcija protovestijara. To je jedna od najodgovornijih funkcija i zaduženja na dvoru kralja i oblasnog gospodara. Pripadala je samo najpovjerljivijim osobama, sposobnim i obrazovanim, a predviđala je nadzor nad dvorskom blagajnom i prihodima (Jurčević, 2016, str. 54). U navedenoj tvorenici uočavamo prefiks, odnosno prvi element riječi koja potječe iz grčkoga jezika, a to je proto- (grč. $\pi \rho \tilde{\omega} \tau o \varsigma)$, što bi označavalo nešto što je prvo, odnosno prvi, glavni, najraniji, najviši, najugledniji (Anić, Klaić, Domović, 2001, str. 1178). Navedeni rječnik nema objašnjenje za protovistijara, ali protonotara tumači kao prvi pisar, glavni sekretar (ili: tajnik); prvi svećenik poslije patrijarha u Carigradu; u Kat. Crkvi: titula visokog svećenika, po rangu odmah iza biskupa, a obavlja sve poslove koji se tiču pape i Kat. Crkve (Isto, str. 11791180; Usp. Rebić, 1997, str. 457).

U srednjovjekovnoj Srbiji upravitelj državnih i vladarskih financija (Brodnjak, 1992, str. 457), a pov. u Bizantskom Carstvu a. nadzornik careve garderobe b. kasnije, upravitelj carskih odnosno državnih financija srgrč. prōtovestiários = PROTO- + lat. vestis: odijelo (Hrvatski enciklopedijski rječnik, str. 1067). Primjeri iz srednjovjekovnih isprava pokazat će koje je sve službe i djelatnosti obavljao protovistijar na bosanskim i humskim dvorovima. Već će se u prvome primjeru vidjeti da je vršio službu pisara, a u ostalima da je zastupao Bosnu u Dubrovniku kao uglednik i glavni predstavnik Bosne. Ponekad su povelje ili neke druge dokumente pisale i osobe visokog ranga, obično u slučajevima kada ujedno vrše i funkciju poslanika, kao što je slučaj s protovestijarom Restojem, komornikom Tvrtka II Tvrtkovića, koji piše povelju kralja Tomaša Dubrovniku 1444. god. (Kuna, 2008, str. 332). Truhelka navodi da se u srednjem

\footnotetext{
${ }^{10}$ Taj se leksem opisao, jer se kao i pisarb pojavljuje u drugim izvorima kao sinonim za pisara. Međutim, znamo da je isprave bana Ninoslava pisao jedan od prvih pisara, a to je notarb Paskal kojega smo već spomenuli u prethodnim recima.
} 
vijeku blago velikaša sastojalo djelomice i od dragocjenih odjeća i nakita; ti su se predmeti čuvali također u riznici, a bili su povjereni nadzoru protovistiarevu (Truhelka, 1901, str. 104). Stoga, preostaje nam pitanje može li se protovistijarb uvrstiti u navedeni sinonimski niz? Budući da nije samo obavljao službu predstavnika i kancelarijske službe tajnika, bilježnika, već i pisarske djelatnosti i to kod bosanskih kraljeva (kralja Tomaša, kralja Dabiše, Tvrtka I. i kraljice Jelene), dakle ne kako navodi Brodnjak, samo u Srbiji, leksem se protovistijarb uvrstio u navedeni sinonimski niz kao bliskoznačnica srednjovjekovne administrativne službe. Primjere i oblike tog grecizma i historizma donosimo pregledno u onoliko primjera u koliko se i pojavljuje:

- ja restoe protobistarb upisahь po zapovidi g(ospo)d(i)na mi krala tomaša (P. 97, 104)

- našega kralevbstva protobistar knezb restoe z bratbeômb (P. 97)

- da je vidomo vsakomu človeku malômu i v(e)likômu kako kralvbstvu mi knezb i vlastele dubrovačci doslaše posaobinômb počtenoga muža protobistb(i)jara žoretu našega virbnoga slugu i protobistb(i)jara koi kralevbstvu mi govori velmi mudro i počteno i nasb veomi umileno i velmi vb vsemb počteno moli ôdb strane rečenihb vlastelı grada dubrovnika (P. 48)

- i ĉo bi r(e)če rečeni g(ospo)d(i)nь protovestijarbôd naše strane viruite mu naše ti su rêči (P. 43)

- i tui kuĵju izdaite g(ospo)d(i)nu protovestiaru (kako pride) u vaš gradb (P. 34)

- i vlastele tako mi e pov(i)dilı protovistarb žore da e vaša prêêzanı ka $m(e) n i$ toi učinila kako da ste uzeli moe zaklade u svoe ruke ôd nališka na tomb zahvalamo (P. 68)

- i m(e)ni slišavbše podobne molbe koe vi poručaste po rečenomb protovistarêi žoreti $\mathrm{i}$ vam se umolismo na to i pisasmo po našoi poveli ku vamb poslasmo po našemb virbnomb sluzi knezu grbguru milatotovijiju s oôvimi mi listomb (P. 49)

- i razumismo kakô namb bihote poručili posaôbine po našemb virıni sluzi g(ospo)d(i)nu protovistaru žoreti ô vašihı potrêbahı i ôd našihı (P. 49)

- a tomu ručnici i svêdoci dvorbski kral(e)vstva mi gojanı dragoslaviĵ̀ i knezb dragî̂b hrvatiniĵb i našb vêrni i vbzljubljeni protovistijar žore i našb počteni kapelanı popь milacı i jurai voletî̂b (P. 39, 45)

- my jesmo z bogomb zdravo i radi smo slišati ô vašemb zdraviju i tamo poslasmo protovistijara našega $g(o s p o) d(i) n a$ trife da co vamb uzgovori ôd(b) naše strane da ga vêrujete (P. 33, 39, 43, 45)

- ônei litre čimı mi je dlıžьnь dragoje bevenjutiĵs podaite mi (i)hь protovistijaru našemu ônui $\cdot p \cdot(80)$ litbr kakono je govoreno ô tomb meju nami (P. 32)

$\mathrm{U}$ analiziranome je sinonimskom nizu leksem pisarb staroslavenski, dok su ostali nazivi za djelatnost pisara posuđenice (grecizmi i latinizmi) i to je jedna od najčešćih leksičkih osobitosti među sinonimičnim jedinicama u kontekstu (Usp. Petrović, 2005, str. 182). Može se i potvrditi da je pisarb hiperonim ostalim leksemima, jer je dominantna središnja riječ i stilski neutralna i jer svojim značenjem pokriva cijeli niz (Tafra, 1995, str. 18). Međutim, utvrdili smo da je staroslavenski pismę istokao i grčki gramma što znači slovo, a iz primjera se logofeta može zaključiti da je službenik obavljao samo pisarske dužnosti, što te lekseme dovodi u istoznačne odnose. Drugi su leksemi u navedenom nizu u bliskoznačnome odnosu, jer nisu obavljali samo pisarske dužnosti. Stoga bismotaj niz mogli podijeliti na istoznačnice: pisarb (pisbcb), gramatikb (gramatigь) i logofetb i bliskoznačnice: dijakb, notarb i protovistijarb.

Među navedenim se sinonimima može uočiti jedna ispravnost, a to je da su pisarske dužnosti, dužnosti tajnika, kancelara i svih onih službi koje su ti ljudi obnašali u svoje vrijeme činile ih najučenijima u njihovoj okolini i obrazovnim krugovima u kojima su pisali i slali svoje dokumente. Potpis pisara davao je veću pravnu valjanost poveljama isto onako kao potpisi vlastele koja se s vladarom zaklinju (Babić, 1972, str. 109). Njihov je posao iziskivao veliku 
odgovornost i njihovu radu možemo zahvaliti što smo danas u mogućnostida na osnovi njihovih tekstova provodimo različite jezične analize.

\section{ZAKLUČAK}

Srednjovjekovne bosanske i humske administrativne ćirilične isprave omogućuju lingvističku analizu s brojnih jezičnih aspekata. Isprave su se javile upravo onda kada je bosanska država bila na vrhuncu svoje moći, a jezik i pismo u razvoju. U srednjovjekovlju se brojnim kancelarijama nastojala stvoriti komunikacija jer su pisari upravo tom vrstom komunikacije proširivali značenje leksema koji se promatraju i proučavaju ne samo kroz vrijeme njihova nastanka nego i kroz prostornu i stilsku raslojenost leksika.

Analiziran je tek mali dio onoga što nam definirani korpus nudi svojim plodonosnim sinonimskim nizovima. Nijedan živi i govoreni jezik na svijetu nije isključivo samo svoj. Svaki ima posuđenih riječi iz drugih jezika, a posebno se to vidi u sinonimskom nizu: pisarb (pisbcb), dijakb, gramatikb (gramatigb), logofetb, notarb, protovistijarb. U navedenom je nizu leksem pisarb staroslavenskoga podrijetla, dok su ostali leksemi posuđenice iz grčkoga i latinskog jezika. Navedeni leksemi tvore sinonimski niz, što znači da imaju isto ili slično značenje. Međutim, podijelili smo ih na istoznačnice pisarb (pisbcb), gramatikb (gramatigb) i logofetb i na bliskoznačnice dijakb, notarb, protovistijarb. Hiperonim bi cijelome nizu bio leksem pisarb. Kako se ljudi kreću i kako se događaju seobe ljudi, takav se proces odvija i kod riječi. Do koje će mjere pojedini jezici biti u dodiru s drugima, ovisi o razlikama u kulturi naroda, o tome kako i kada su pisari prelazili iz jedne u drugu kancelariju, zatim je li riječ o prirodnim dodirima jezika, je li riječ o osvajačima i njihovim silom nametnutim utjecajima ili o samo pukom pomodarstvu. Sinonimi su se tako širili, ponekad se upotrebljavali u istoj ispravi, što ih čini kontaktnim sinonimima. Jezična analiza koja je provedena podastrtim presjekom nastoji proučiti cijeli niz leksema koji imaju bliskoznačne odnosno istoznačne odnose u određenim kontekstima u navedenom korpusu, a o kojima bi se mogle napisati brojne studije i analize.

Korespondencija bosanskih i humskih i dubrovačkih vladara i velmoža tek su u novije vrijeme predmet istraživanja i analiziranja jezične problematike tog epistolarnog žanra. Ako za neku posuđenicu i imamo slavenski (hrvatski) leksem, moramo obratiti pozornost podudaraju li se sadržajno posuđenica i slavenska (hrvatska) riječ. Provedenom raščlambom nije sve rečeno, nego su otvorena brojna pitanja i nastojanja za spoznavanjem svih sinonimskih odnosa među leksemima u srednjovjekovnim bosanskim i humskim ćiriličnim ispravama.

\section{LITERATURA}

Akademijin Rječnik = Rječnik hrvatskoga ili srpskoga jezika (1886.), sv. 8. Zagreb : Jugoslavenska akademija znanosti i umjetnosti.

Akademijin Rječnik = Rječnik hrvatskoga ili srpskoga jezika (1886.), sv. 10. Zagreb : Jugoslavenska akademija znanosti i umjetnosti.

Anić, Š., Klaić, N. i Domović, Ž. (2001). Rječnik stranih riječi. Zagreb: SANI-PLUS.

Anić, V. (2004). Veliki rječnik hrvatskog jezika. Zagreb: Novi liber.

Babić, A. (1972). Iz istorije srednjovjekovne Bosne. Sarajevo: Svjetlost.

Barić, B. (2013). Razvoj hrvatskoga leksika na razmeđi tisućljeća. Zagreb: doktorski rad.

Brković, M. (1998). Isprave hrvatskih narodnih vladara i latinske isprave bosansko-humskih vladara i velmoža. Zadar, Mostar: Zavod za povijesne znanosti HAZU i Ziral.

Brković, M. (2002). Srednjovjekovna Bosna i Hum - identitet i kontinuitet. Mostar: Crkva na kamenu. 
Brodnjak, V. (1992). Rječnik razlika između hrvatskoga i srpskoga jezika. Zagreb: Školske novine, Hrvatska sveučilišna naklada.

Čremošnik, G. (1950). Bosanske i humske povelje srednjeg vijeka II, Nova serija, sv. IV-V. Sarajevo: Glasnik Zemaljskog muzeja u Sarajevu.

Damjanović, S. (2003). Staroslavenski jezik. Zagreb: Hrvatska sveučilišna naklada.

Damjanović, St. i dr. (2004). Mali staroslavensko-hrvatski rječnik. Zagreb: Matica hrvatska.

Dizdar, M. (1997). Antologija starih bosanskih tekstova, Sarajevo.

Gluhak, A. (1993). Hrvatski etimološki rječnik. Zagreb: August Cesarec.

Hercigonja, E. (1986). Acta croatica kao predmet književnomedievističkog studija. Filologija, 14, 109-122.

Hercigonja, E. (2004). Na temeljima hrvatske književne kulture. Zagreb: Matica hrvatska.

Hercigonja, E. (1994). Tropismena i trojezična kultura hrvatskoga srednjovjekovlja. Zagreb: Matica hrvatska.

Hrvatski enciklopedijski rječnik (2002). Zagreb: Novi liber.

Jurčević, I. (2016). Dvorske službe i uređenje dvora vojvode Radoslava Pavlovića. Mostariensia: časopis za humanističke znanosti, 20(1-2), 41-60.

Kuna, H. (2008). Srednjovjekovna bosanska književnost, Sarajevo: Forum Bosnae, 45/08.

Mamić, M. (1996). Jezični savjeti. Zadar: Hrvatsko filološko društvo.

Mihaljević, M. (2002). Terminološki rječnik i norma (uputnice, odrednice i normativne napomene u terminološkom rječniku). Rasprave: Časopis Instituta za hrvatski jezik i jezikoslovlje, 27(1), 191208.

Nakaš, L. (2011). Konkordancijski rječnik ćirilskih povelja srednjovjekovne Bosne, Sarajevo: Društvo za proučavanje srednjovjekovne bosanske historije, knjiga X., Filozofski fakultet u Sarajevu.

Pet stoljeća hrvatske književnosti (1969). Hrvatska književnost srednjeg vijeka. Zagreb: Matica hrvatska, Zora.

Petrović, B. (2005). Sinonimija i sinonimičnost u hrvatskome jeziku. Zagreb: Hrvatska sveučilišna naklada.

Rebić, A. (1997). Mali religijski rječnik. Zagreb: Kršćanska sadašnjost.

Samardžija, M. (1995). Leksikologija s poviješću hrvatskoga jezika. Udžbenik za 4. razred gimnazije. Zagreb: Školska knjiga.

Skok, P. (1995). Etimologijski rječnik hrvatskoga ili srpskoga jezika. Zagreb: Jugoslavenska akademija znanost i umjetnosti.

Šabić, I. (2014). Onomastička analiza bosanskohercegovačkih srednjovjekovnih administrativnih tekstova i stećaka. Osijek: doktorski rad.

Šetka, J. (1976). Hrvatska kršćanska terminologija. Split: Marija.

Šimundić, M. (1996). Jezik darovnice bosanskoga kralja Stjepana Dabiše izdane 1395. U: Markotić, Ante F. (ur.). Ljubuški kraj, ljudi i vrijeme (str. 87-102). Mostar: Ziral i Zagreb:

Tafra, B. (1996). Bliskoznačni odnosi u leksiku. Filologija, 26, 73-84.

Tafra, B.(1995). Jezikoslovna razdvojba. Zagreb: Matica hrvatska.

Tafra, Br. (2003). Leksičke pogreške zbog sličnosti. Govor, 20(1-2), 431-448.

Truhelka, Ć. (1901). Državno i sudbeno ustrojstvo Bosne u doba prije Turaka. Glasnik Zemaljskoga muzeja, knj. 13, (str. 71-112).

Vrana, J. (1957). Tko je pisao najstarije dubrovačke ćirilske isprave. Slovo, 6-7-8, 311-334.

Zrinjan, S. (2006). Hrvatski jezik 4. Udžbenik za četvrti razred četverogodišnjih strukovnih škola. Zagreb: Alfa. 


\title{
A Synonymic Sequence for the Work of Scriveners in Medieval Bosnian and Hum Chancellaries
}

\begin{abstract}
This paper will study the lexemes that characterize the activities of scriveners in the Bosnian and Hum offices. The corpus consists of 130 medieval Bosnian-Hum texts, from the document of ban (viceroy) Kulin in 1189 to the charter of the Vlatković brothers in 1493. In formulas, the most common dates are found with the name of the scrivener and the function he performed. Thus, a complete synonymic sequence for the work of scriveners was created in the studied corpus. This sequence is: pisarb (pisbcb), dijakb, gramatikb (gramatigb), logofetb, protovistijarb. This synonymic sequence is of utmost importance for the further study of other lexemes in the medieval corpus. Scriveners are the ones to be thanked for the appearance of writing, the nurturing of correspondence, administration in general, and the language in which the documents were written. The development of literacy in the Bosnian-Hum office, correspondence with the office in Dubrovnik, the emergence and development of the Croatian Cyrillic or Bosančica are the contents that have lately attracted linguists. Documents are the best reflection of the office. They show the letter, the language, the style, the authors of the documents, the contracting authorities, the place where they were issued and to whom they were sent and much more information. An insight into the administrative texts of the Bosnian Hum Office reveals a whole range of different lexemes. The scriveners and their texts, as well as the area in which they were made are an inexhaustible theme not only because of their historical significance and content, but because of the graphics, language and words of the Bosnian-Hum Middle Ages.
\end{abstract}

Keywords: Bosnian-Hum offices, scrivener: pisarb (pisbcb), dijakb, gramatikb (gramatigb), logofetb, protovistijarb.

\section{Synonymische Reihe für die schriftstellerische Tätigkeit in mittelalterlichen Ämtern von Bosnien und Hum}

Zusammenfassung: In dieser Arbeit werden die Lexeme betrachtet, die das Schreibwesen in Ämtern von Bosnien und Hum bezeichnen. Das Textkorpus besteht aus 130 mittelalterlichen Texten von Bosnien und Hum seit der Urkunde des Ban Kulin aus dem Jahr 1189 bis zur Bulle der Gebrüder Vlatković aus dem Jahr 1493. In den Formeln sind am häufigsten die Datumseinträge zu finden, die im Zusammenhang mit dem Namen eines Schreibers und mit dem von ihm bekleideten Amt stehen. So wurde im Forschungskorpus eine komplette synonymische Reihe für diese Schreibtätigkeit geschaffen. Das sind: pisarb (pisbcb), dijakb, gramatikb (gramatigb), logofetb, notarb, protovistijarb. Diese synonymische Reihe ist der wichtigste Ausgangspunkt für die weitere wissenschaftliche Untersuchung der restlichen Lexeme im mittelalterlichen Textkorpus. Den damaligen Schreibern sind wir für Vieles dankbar, z.B. für das Aussehen von Schriften, die Sorge um die damalige Korrespodenz, die Verwaltung im allgemeinen und für die Sprache, in der die Schriften erstellt wurden. Die Entwicklung von Schreibkunde in den Ämtern von Bosnien und Hum, die Korrespodenz mit den Ämtern in Dubrovnik, Entstehung und Entwicklung der kroatischen Kyriliza oder Bosančica, sind in letzter Zeit Inhalte, mit denen sich Sprachforscher beschäftigen. In dem Sinne sind die Urkunden die besten Widerspiegelungen der damaligen Ämter. Sie stellen die Schrift, die Sprache, den Stil, die Autoren und die Besteller von Inschriften, den Ort, an dem sie erstellt wurden und die Adressaten, wie auch viele andere Angaben, dar.

Die Einsicht in die Ämter von Bosnien und Hum führte zur Entdeckung einer ganzen Reihe von verschiedenen Lexemen. Die Schreiber sind, genau wie ihre Texte und wie die Orte, an denen die Texte entstanden sind, eine unversiegbare Quelle von Themen, nicht nur wegen ihrer geschichtlichen Bedeutung und wegen der Inhalte, sondern auch wegen der Graphie, der Sprache und des Wortschatzes im Mittelaltertum von Bosnien und Hum.

Schlüsselwörter: Ämter von Bosnien und Hum, Schreiber: pisarb (pisьcь), dijakb, gramatikb (gramatigb), logofetb, notarb, protovistijarb. 